\title{
INTERPRETATION OF MAGNETIC DATA BASED ON EULER DECONVOLUTION: ANALYSIS OF THE MAIN HOST GOLD STRUCTURE IN THE NORTHEASTERN PORTION OF THE QUADRILÁTERO FERRÍFERO, MG, BRAZIL
}

\author{
Thiago José Augusto Madeira ${ }^{1}$, Maria Silvia Carvalho Barbosa ${ }^{1}$ and Antonino Juarez Borges ${ }^{2}$
}

\begin{abstract}
The study of the geometry and kinematics of deep geological structures, bearing mineralization, has advanced greatly by the aggressive progress of geophysical techniques over the last decades. The gold mineralization located in the Quadrilátero Ferrífero has its genesis controlled by shear zones. The geophysical analysis (aeromagnetic and aero-electromagnetic) by means of two-dimensional magnetic data inversion profiles (Euler deconvolution) and later interpolation, provided the 3D configuration of a tectonic-structural geological model, explaining the spatial configuration of lithostratigraphic and structural units, and kinematics features of the main shear zone mineralized in gold in the northeastern portion of the Quadrilátero Ferrifero. The processing of airborne geophysical magnetic data of the Rio das Velhas Project provided the generation of inversion profiles with outputs up to $5000 \mathrm{~m}$ deep, opening new windows for gold prospection at the surroundings of the main gold mineralized structure in the Quadrilátero Ferrífero. The integration of geological, geophysical data and field observations was essential for the final results of this work.
\end{abstract}

Keywords: South America, mineral prospecting, Euler deconvolution.

RESUMO. 0 estudo da geometria e cinemática de estruturas geológicas de alta profundidade, portadoras de mineralizações, tem sido cada vez mais viabilizado pelo avanço agressivo das técnicas geofísicas nas últimas décadas. As mineralizações de ouro localizadas no Quadrilátero Ferrífero têm a sua gênese controlada por zonas de cisalhamento. A análise geofísica (magnetometria e eletromagnetometria de dados aerolevantados) através de perfis de inversão bidimensionais (deconvolução de Euler) e posterior interpolação, possibilitou a configuração 3D de um modelo geológico tectono-estrutural, que permitisse uma análise e sugestão descritiva da configuração espacial de unidades litoestratigráficas, estruturais e cinemática da principal zona de cisalhamento mineralizada em ouro do nordeste do Quadrilátero Ferrífero. 0 processamento de dados magnetométricos aerogeofísicos do Projeto Rio das Velhas possibilitou a geração de perfis de inversão com respostas de até $5000 \mathrm{~m}$ de profundidade, abrindo novas janelas para a prospecção de ouro nas adjacências da principal estrutura mineralizada em ouro do Quadrilátero Ferrífero. A integração de dados geológicos, aerogeofísicos e de observações de campo foi fundamental para os resultados finais deste trabalho.

Palavras-chave: América do Sul, prospecção mineral, deconvolução de Euler.

\footnotetext{
1 Universidade Federal de Ouro Preto, Department of Geology, School of Mine, Rua Nove, 857, Campus UFOP, 35400-000 Ouro Preto, MG, Brazil. Phone: +55(31) 3559-1600 - E-mails: madeira_thiago@yahoo.com; madeira_thiago@hotmail.com; mscbarbosa@gmail.com

${ }^{2}$ CPRM - Serviço Geológico do Brasil, Avenida Brasil, 1731, Funcionários, 30140-002 Belo Horizonte, MG, Brazil. Phone: +55(31) 3878-0307; Fax: +55(31) 3878-0383

- E-mail: antonino.borges@cprm.gov.br
} 


\section{INTRODUCTION}

Over the last decades, the structural geology has experienced major progress mainly related to the processes and mechanisms of nucleation and development of structures and their kinematic significance (Endo, 1997). The geometry, kinematics and dynamics of thrust faults and folds genetically related have been the subject of significant scientific interest during the past years (Rolim \& Alkmim, 2004). At the same time, geophysics has been effectively developed due to the broad improvement of digital techniques to integrate different types of data, combined with analytical tools, handling and process of data analysis being executed with agility and consistent results with the actual observations in the field (Madeira, 2011; Madeira \& Barbosa, 2012).

Located in the southern portion of São Francisco Craton, in the Northeastern portion of the Quadrilátero Ferrífero (QFe), the area of study is distinguished by the presence of several gold mines, and it was selected based on the airborne survey coverage Departamento Nacional de Pesquisa Mineral/Serviço Geológico Brasileiro (DNPM/CPRM) (Baltazar et al., 2005) - Rio das VeIhas Project (Fig. 1). The area is $300 \mathrm{~km}^{2}$ and covers the boundaries of the municipalities of Caeté, Sabará and Raposos covering the grids of Caeté, Belo Horizonte, Itabirité and Gandarela (Baltazar et al., 2005).

The qualitative analysis of geophysical maps enabled the individualization of lithofacies, visualization of structural lineaments and structures presenting rotational kinematics, to infer the depth of lithostratigraphic units and to identify areas featuring hydrothermal alteration favorable to the mineral prospection. Quantitative analysis of the inversion of magnetic data provided the partitioning of structures at different depth intervals and the identification of planar structures with depths up to $5000 \mathrm{~m}$.

After the data inversion (Euler deconvolution) it was possible to obtain the configuration of a 3D tectonic-structural geological model by integrating a high number of two-dimensional models. This model can be applied to improve the structural analysis at crustal level of estimated depths. The work herein aims to apply geophysical magnetic data inversion to generate a threedimensional model (3D) with deep crustal level information, and the macro scale assessment of the deformation related to the mechanisms and processes ruling mobilization/remobilization and concentration of gold in host rocks and structures close to mineralized shear zone.

\section{STRUCTURAL AND GEOLOGICAL CONTEXT}

Almeida (1977) understanding the cratons as transitional units records that the São Francisco Craton (SFC) had an anteces- sor, named Paramirim Craton, stabilized after the Jequié Event (2,9-2.7 Ga) and that its margins would have been reconditioned during the Transamazonic Event and, in a smaller extent, once again during the Brazilian Event. The SFC would have been the result of the Paramirim Craton with accretions of the Transamazonic Event and action by the Brazilian Event. In the south edge of SFC is located, preserved and exposed the Mineiro Belt (Teixeira et al., 1996), wich is a small portion of the outer belt Paleoproterozoic orogeny. Furthermore, the Quadrilátero Ferrífero is settled in the eastern portion of the Mineiro Belt.

According to Bizzi et al. (2003), during the Jequié orogenic cycle the Rio das Velhas greenstone belt (RVGB), developed within a complete Wilson cycle with taphrogenesis phase followed by orogenesis, felsic volcanism calci-alkaline presenting tonalitic intrusions, metamorphism and deformation. The Rio das Velhas greenstone belt was affected by two Transamazonic strain (e.g. Alkmim et al., 1994; Alkmim \& Marshak, 1998; Zucchetti \& Baltazar, 1998; CPRM, 2011). The first deformation event (D1) generated NE-SW trending folds and thrust faults, after the southwest convergence and collision of two passive margins around 2.125 Ga (Almeida, 2004; Endo et al., 2005). The second phase is characterized by extensional structures related to the development of granite-gneiss domes (D2) deforming the supracrustal rocks $(2.095 \mathrm{Ga})$ and resulting in the orogenic collapse during the Transamazonic Event.

By the end of the Mesoproterozoic, a maritime basin in the eastern part of the current São Francisco Craton was formed, impacting the Transamazonic Orogen, in the QFe, most likely representing the collisional phase and collapse of a Wilson cycle during the Paleoproterozoic. Then the Espinhaço rift took place, opening the basin and intruding diabase dikes. During this deformation phase a compressional event was also observed in the eastern boundary of QFe, generating N-S oriented structures. This last event is known as Brazilian Orogen (0.7-0.45 Ga) and it is associated with a regional progressive metamorphism of medium green schist facies. It has generated a fold and faults belt dipping to the west, resulting in the suture of the supercontinent Gondwana.

The Brazilian Event is the most remarkable within the QFe, taking over the entire central-eastern portion, being represented by regional foliation of NW, NS and NE direction related to the frontal and oblique ramps of the thrust fronts, to which this foliation is related. Mineral lineations and stretching as well as the associated intersection lineation dipping from E to ESE, are related to a N-S tectonic shortening (Almeida, 2004; Endo et al., 2005). 


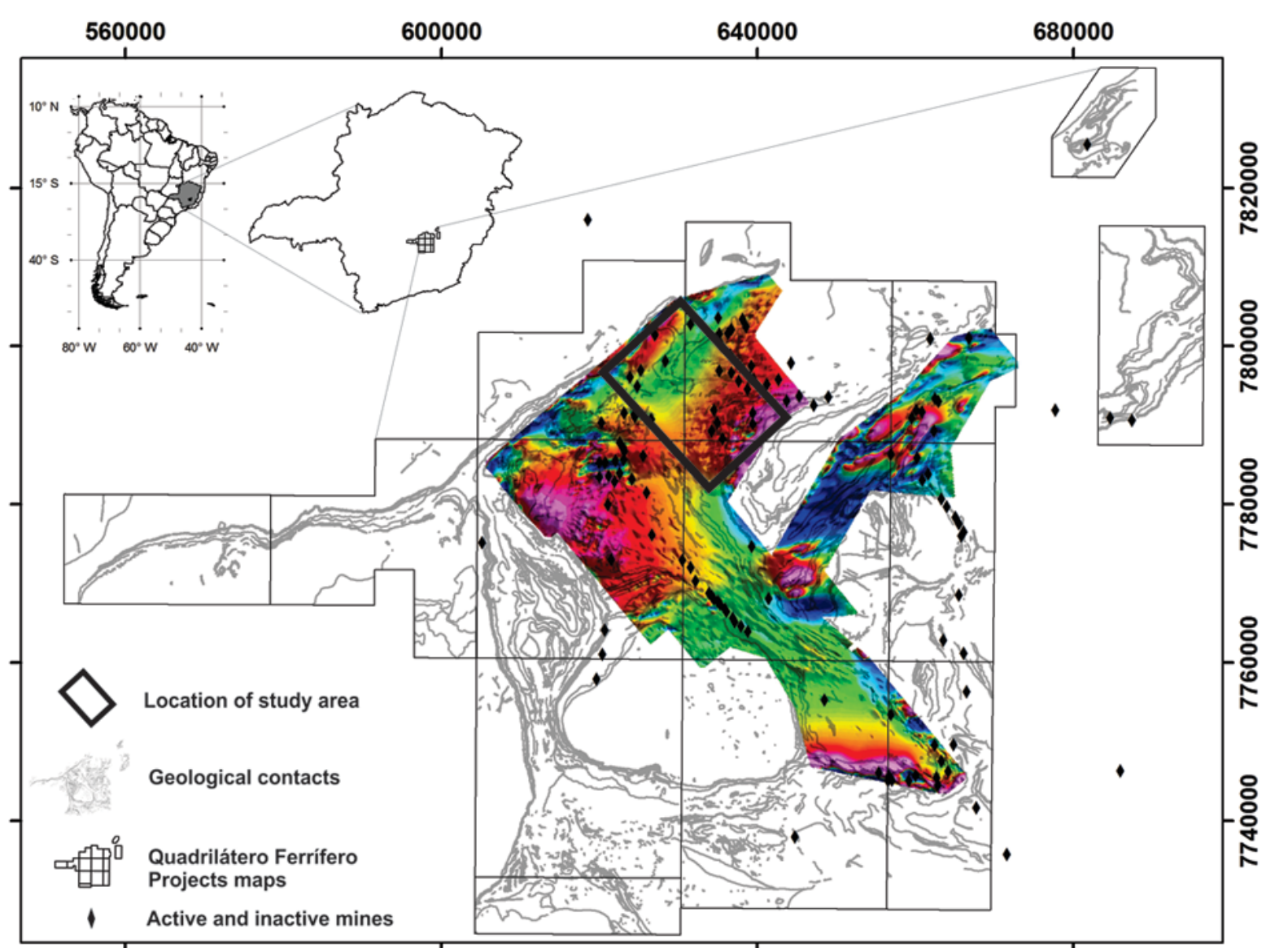

Figure 1 - The study area is located in the northeast of the QFe. The gold mines are represented over the map magnetic, Analytical Signal, of Rio das Velhas Project showing major mines deactivated and activated in the QFe (modified from Ladeira, 1991).

The study of integrated structural, petrographic, petrological data and field caracterization of RVGB shows the units are distributed according to four major lithostructural domains, characterized by distinct stratigraphic columns (Zucchetti \& Baltazar, 1998). That considered, it was proposed, as a preliminary measure, the subdivision of the area of the greenstone exposure, within the QFe, in four tectonic blocks (Fig. 2). The study area is located in the Caeté Block which, according with Baltazar \& Zucchetti (1998), is the only one presenting all the elements of a greenstone sequence, from the basic-ultrabasic metavolcanic rocks, metavolcaniclastic sequence and resedimented up to the coarse non-marine clastic metasediments of Maquiné Group, with greenschist facies metamorphism.

Some lineaments of the QFe (e.g. Juca Vieira, Areão Tapera and São Vicente) even being reactivated during the Brazilian cycle, would have been generated during the deformational Event F1, configuring old thrust systems. Such assumption is based on some observation, still inconclusive, but which shall be considered, especially regarding the São Vicente lineament (Zucchetti
\& Baltazar, 1998). Some of its special features reinforce such assumption: gold mineralization throughout its length; geometry shaping curvilinear trace; their overlapping by the FundãoCambotas System in the Mariana anticline ending; non-marine clastic sediments depositional chute (coastal and by rainwater) of Maquiné Group (Archean). Therefore, such lineaments would have been generated by the time of the inversion of the basin, indicated by large recumbent south-verging folding featuring axis in the same direction (NW-SE). The structures aforementioned are consistent with one event of crustal shortening, where blocks in the northern portion were uplifted towards the south (Correa Neto \& Baltazar, 1995).

\section{INTERPRETATION OF MAGNETIC DATA}

Based on Euler's Homogeneity Equation, Thompson (1982) and Reid et al. (1990) started a series of studies relating the density distribution and/or heterogeneous magnetic susceptibility of sources with their geometry at depth. With no interference or 


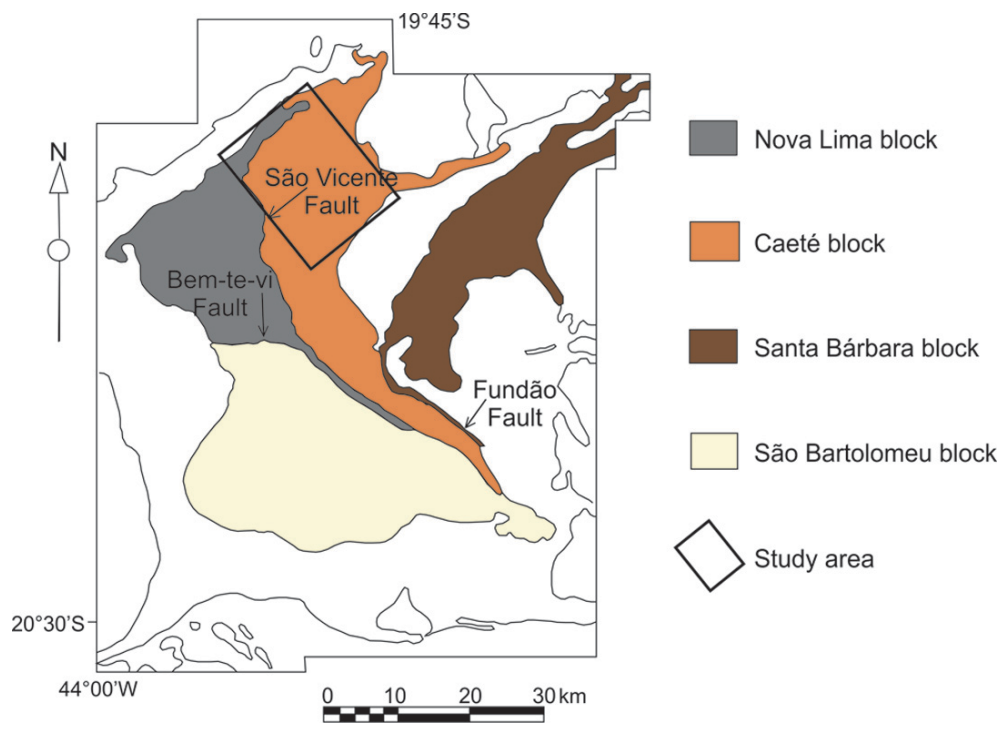

Figure 2 - The Rio das Velhas greenstone belt units were grouped into tectonic domains, called: Nova Lima, Caeté, Santa Bárbara and São Bartolomeu, portraying different petrogenetic environments (modified from Zucchetti \& Baltazar, 1998).

noises from other sources, any magnetic anomaly produced by a three-dimensional point source suits the Euler Homogeneity Equation, Eq. (1).

$$
\left(x-x_{0}\right) \frac{\partial T}{\partial x}+\left(y-y_{0}\right) \frac{\partial T}{\partial y}+\left(z-z_{0}\right) \frac{\partial T}{\partial z}=\eta T
$$

The equation expresses the anomaly of the total field $T(x, y, z)$ produced by a three-dimensional point source located by the coordinates $x_{0}, y_{0}, z_{0}$ of the Cartesian System which is submitted to a decrease of intensity to a rate $\eta$, with the increase of the distance between the source and measured point. The parameter $\eta$ is an indicator of the geometric shape of the anomaly and therefore it is called structural index.

Therefore we have that the Euler deconvolution is a process of inversion by least squares, from which the anomalous magnetic field values and of one selected structural index aim to solve the Euler equations, generating brief solutions for the depth and geographic position of all the existing magnetic sources in the survey area (Reid et al., 1990).

According to Keating \& Pilkington (2004) the Euler deconvolution and Analytical Signal are used for semi-automatic interpretation of magnetic data to outline more contact zones and get a quick estimate of the depth of the top of the anomaly cause source. For the Euler deconvolution the quality of the source estimate depends mainly on the selection of a suitable structural index, which is a function of the geometry the body causing the anomaly. This technique can only be applied to homogeneous functions, like the case the magnetic field due to contacts and thin dikes. Fortunately, several complex geological structures can approximately present this simple geometry.

The geological database for this work consists of geological maps of the QFe, in the 1:50000 scale, of QFe Geology Project - Integrating and Cartographic Correction in GIS, resulting from geological mapping project agreement by USGS/DNPM (1952-1969) and the integration with geological mapping of the agreement DNPM/CPRM (1992-1996). The integration Projects, the final output of these agreements, is a GIS of the integrated geological map of the QFe from maps of 1:25000 scale by USGS/DNPM and DNPM/CPRM Projects (Baltazar et al., 2005).

The geophysical data (aeromagnetic and aero-electromagnetic) gathered the information resultant from the Geology of Quadrilátero Ferrífero Project and is part of the program Distritos Mineiro (Mining Districts), DNPM, Províncias Minerais (Minerals Hosting Provinces), CPRM, called Rio das Velhas Project (RVP), Zucchetti et al. (1996). For the study herein, this database is limited to the magnetic data, which was acquired using a Bell helicopter for detailed study. The production lines present N40W direction, and the control lines present N50E direction and are equidistant, respectively, $250 \mathrm{~m}$ and $5000 \mathrm{~m}$ (Hildenbrand \& Perez da Gama, 1993). The flight height was set to $60 \mathrm{~m}$, keeping the cesium vapour magnetic sensor at $0.01 \mathrm{nT}$ precision. The system was mounted in a bird, $45 \mathrm{~m}$ above the ground. The samples were collected at 0.1 second intervals (Zucchetti et al., 1996).

The magnetic data of the Rio das Velhas Project (RVP) were 
preprocessed by CPRM, the data had IGRF subtracted, the leveling (and micro-leveling) of all data to a common base and the removal of regional trend. The magnetic data had the field anomalous channel, already corrected, interpolated by the method of minimum curvature in regular grid of $250 \mathrm{~m}$ by the software Geosoft Oasis Montaj (Fig. 3). The derivate maps (horizontal, vertical of first and second order) were generated, from the anomalous magnetic field, in order to visualize and identify the structures, its trends and lateral continuity. Furthermore, upward continuation maps were generated in order to note the structural deepward continuation (Fig. 3).
The inversion of magnetic data of the area was based the Analytical Signal (AS). The Analytical Signal is an effective technique for the determination of the geometrical parameters, such as location of boundaries (geological and structural) and roof depth of anomaly source (Thompson, 1982). Therefore, the twodimensional models obtained from the Euler deconvolution were based on data from the Analytical Signal.

The Euler deconvolution (2D) was obtained from the free version of the Euler software, School of Geosciences - University of the Witwatersrand. One hundred profiles have been generated, equidistant $150 \mathrm{~m}$ apart, featuring the direction (N50 $\mathrm{W}$ ) per-

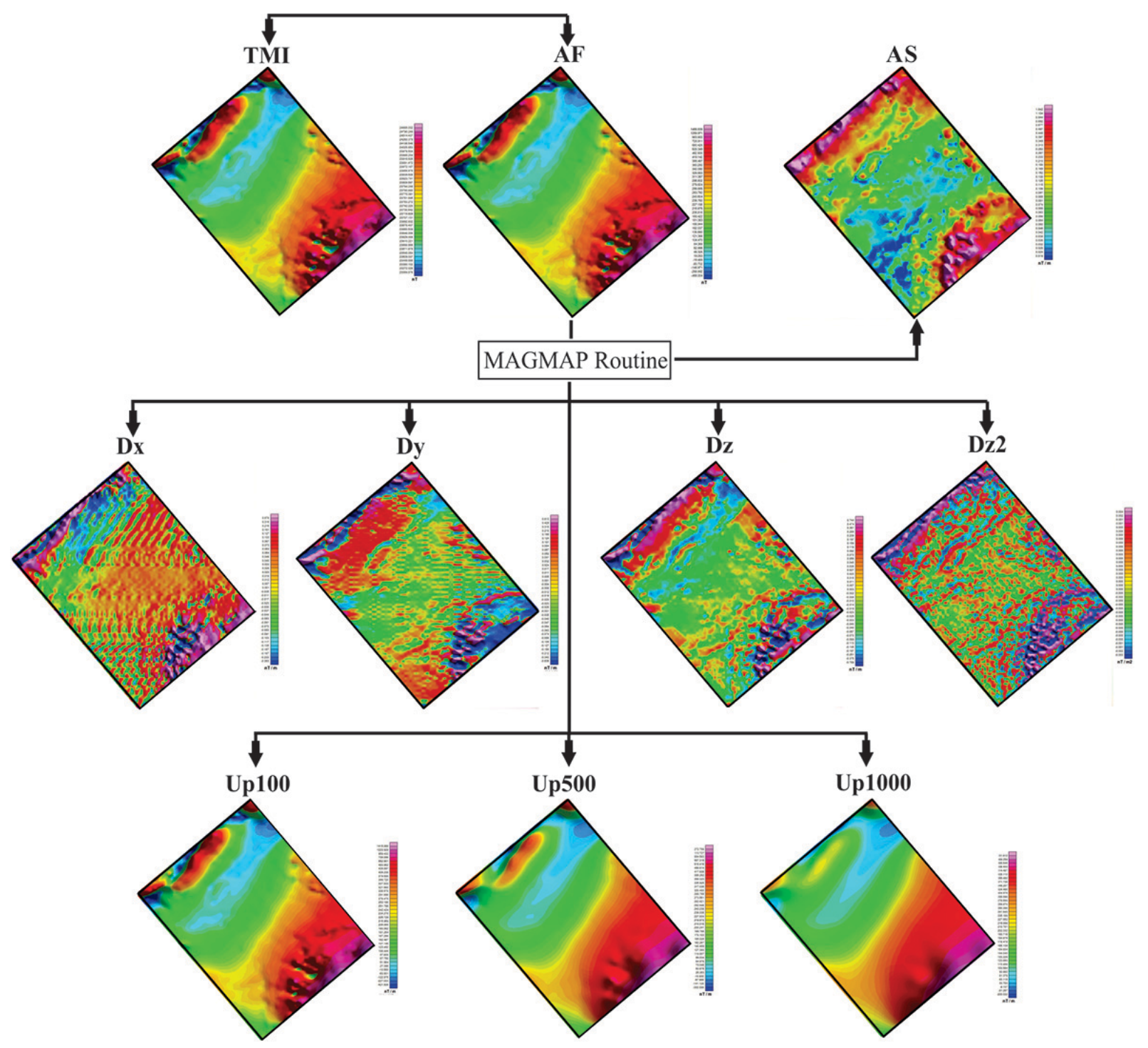

Figure 3 - Flowchart of research methods adopted from magnetic data. TMI - total magnetic intensity; AF - anomalous magnetic field; AS - analytic signal; Dx - first horizontal derivative (E-W); Dy - first horizontal derivative (N-S); Dz - first vertical derivative; Dz2 - second vertical derivative; Up100, Up500 and Up1000 - continued upwards of 100,500 and $1000 \mathrm{~m}$. 


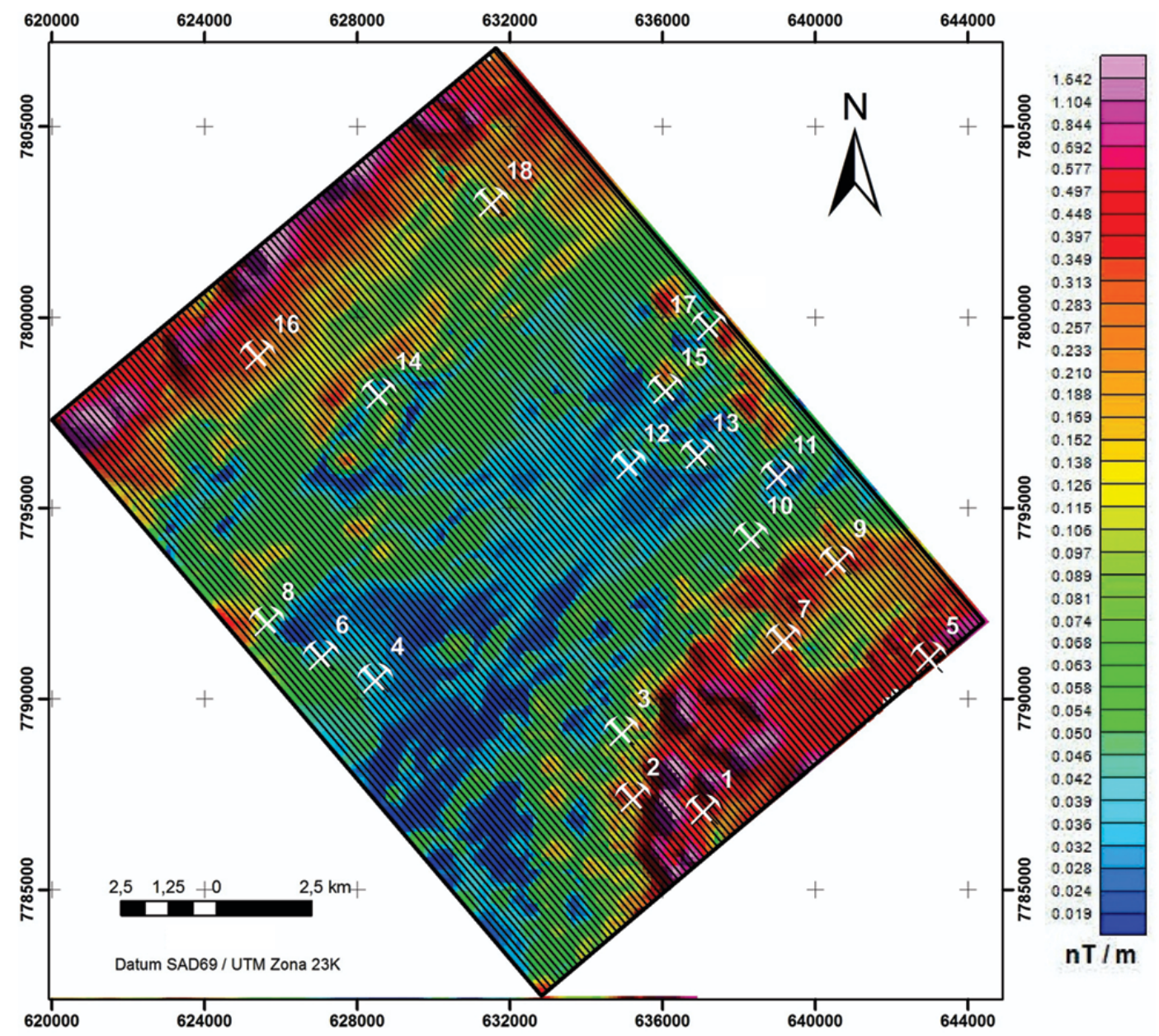

Figure 4 - The figure shows the arrangement of 100 deconvolution profiles over the map of AS with major gold mines (modified from Ladeira, 1991). Active Mines: 14 - Lamego and 18 - Cuiabá. Inactive Mines: 1 - Cachoeira, 2 - Fernandes, 3 - Cutão, 4 - Morcego, 5 - Congo Soco, 6 - Morro das Bicas, 7 - 0jeriza, 8 - Raposos, 9 - Soares, 10 - Carrapato/Caeté, 11 - Juca Vieira, 12 - Carrancas, 13 - Tinguá, 15 - Veremos, 16 - Terras do Capão, 17 - Adão, 18 - Cuiabá.

pendicular to the main structures and covering the whole area of interest (Fig. 4). The parameters adopted to generate the deconvolution profiles were sampling intervals of $25 \mathrm{~m}$, flying $45 \mathrm{~m}$ high above the ground in accordance with the level of the magnetometer in relation to the RVP survey ground, structural index equal to 1 for planar structures, estimated depth for display the responses of the $5000 \mathrm{~m}$ inversion and the window size 21 (dimensionless unit - for more details see Durrheim \& Cooper, 1998) (Fig. 5). This last item was determined by empirical analysis of the responses from geological data, that is, it was considered the prior knowledge of the petrology and structural geology, according to the literature (Baltazar et al., 2005; Madeira, 2011; Madeira \& Barbosa, 2012). The results presented as crosses (+), in the bottom of the Figure 5, account for the roof depth of anomaly source.

The generation of two-dimensional (2D) profiles provided the quantitative data interpretation, which associated to geolog- ical data of the Quadrilátero Ferrífero Geology Project, has the purpose to estimate the 2D geometry of geological structures in subsurface. The systematic execution of $2 \mathrm{D}$ inversions of 100 parallel profiles (NW-SE trend), Figure 4, followed by the interpolation of the profiles provided a 3D model, which when integrated to the geological data, enabled the understanding of deep structures.

\section{RESULTS AND DISCUSSION}

\section{Qualitative Analysis}

In the Analytical Signal map the highest amplitudes from the magnetic data in the northern and southeastern boundaries of the area was observed (Fig. 6). In the northern portion, the large anomalies correspond to Paleoproterozoic supracrustal rocks from Minas Supergroup - Caraça, Itabira and Piracicaba Groups, 


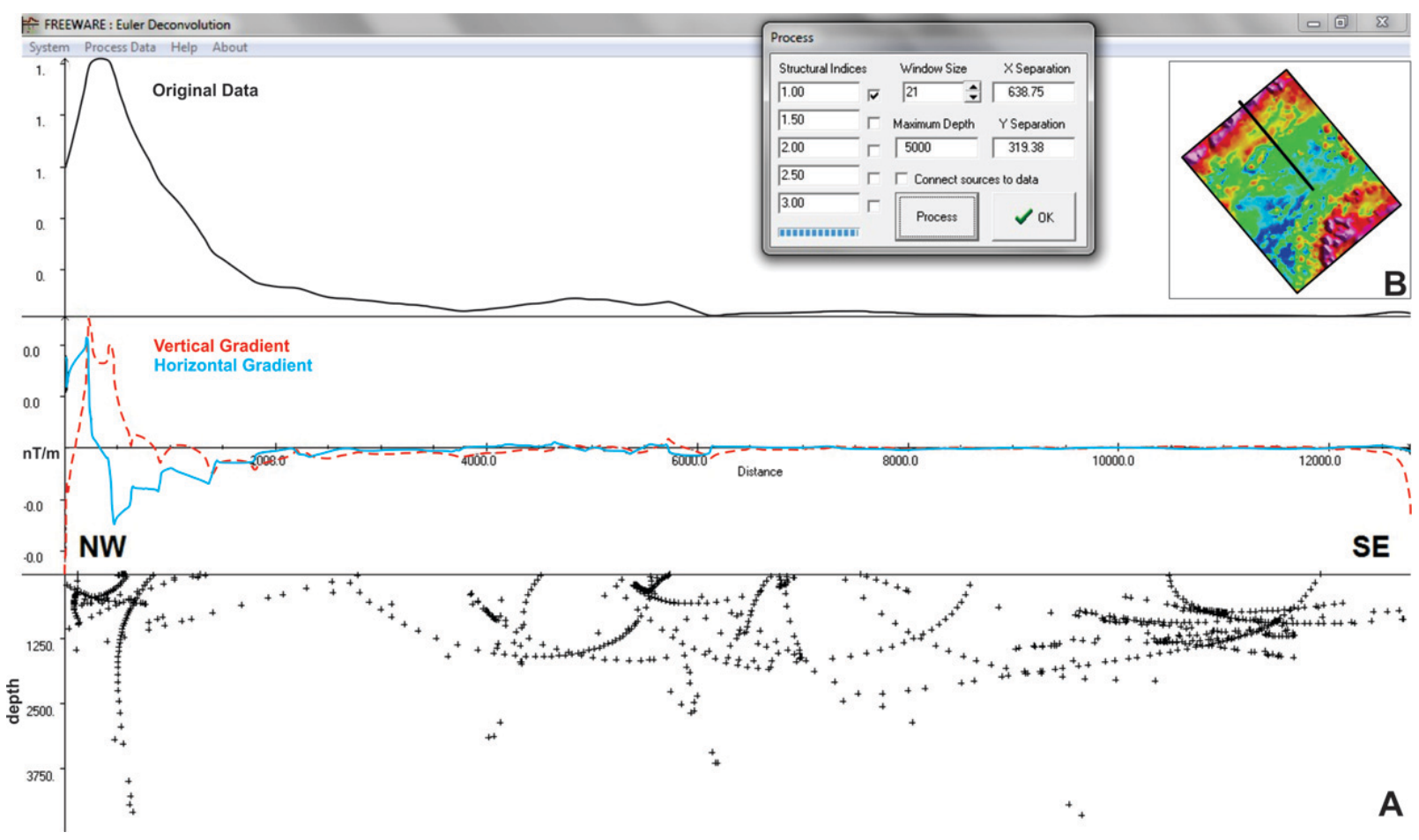

Figure 5 - (A) Display of the 2D Euler free software screen, highlighting the parameters adopted for the inversions. (B) Map of AS with the location of the derivative profile.

being the higher values corresponding to the itabirites from Cauê Formation (Itabira Group). As for the southeastern edge the large anomalies are responses of high magnetic susceptibility of Algoma-type iron formations, Ouro Fino and Morro Vermelho Units from Nova Lima Group of Archean Age. Still in the southeastern boundary, within a small area at the border limit, there is the occurrence of high amplitudes magnetic anomalies related to rocks of the Minas Supergroup, of Caraça Group (Moeda and Batatal Formation) and Itabira Group (Cauê Formation).

The intermediate anomalies from the Analytical Signal map (Fig. 6), of the central and northern areas, correspond to the Mestre Caetano and Córrego do Sítio Units. The Mestre Caetano Unit, defined by Zucchetti \& Baltazar (1998) is metavolcanosedimentary clastic association, consisting of schists of variable composition of sericite and chlorite, in addition to related banded iron formation and quartz-ankerite schist. In the Córrego do Sítio Unit, defined by Zucchetti \& Baltazar (1998) as marine clastic metasedimentary association, predominating schists with quartz, carbonate, mica, chlorite and carbonaceous Phyllite, there is the occurrence, in a smaller extent, iron formations, metapelites and metapsammites with gradational stratification.

The Ribeirão Vermelho, Morro Vermelho and Mindá Units, from the Nova Lima Group, and the Palmital Formation from
Maquiné Group are the ones presenting the lowest values of the magnetic data (Fig. 6). The Mindá Unit covers the central part of the area with schists presenting variable composition of sericite, chlorite and mica. In the eastern portion the low values are represented by the rocks of the Ribeirão Vermelho and Morro Vermelho Units, featuring, respectively, metaconglomerates to metapelites and metabasalts with subordinate felsic metavolcanic rocks. At the extreme southeast, the low values correspond to quartzites from the Palmital Formation (Maquiné Group). Madeira (2011) interpreted the low amplitude of the Analytical Signal in the central and southeastern portion of the area, as a result of the sedimentary cover with low magnetic susceptibility.

Briefly, high magnetic amplitude anomalies (>1.642 nT/m) are related to supracrustal rocks presenting ferromagnetic minerals and (ultra)basic metavolcanic rocks (Telford et al., 1990). The intermediate magnetic anomalies ( 0.125 to $0.692 \mathrm{nT} / \mathrm{m}$ ) are related to the clastic metasedimentary rocks hosting gold mineralization. The low anomalies $(<0.115 \mathrm{nT} / \mathrm{m})$ are represented by clastic sedimentary metavolcanic rocks, metapelites and resedimentary lithofacies association. The variation of the Analytical Signal values for the same geological unit or similar units can be explained by the difference of the rocks' depth. Madeira (2011), in a survey at the same region, describes the wavelength val- 

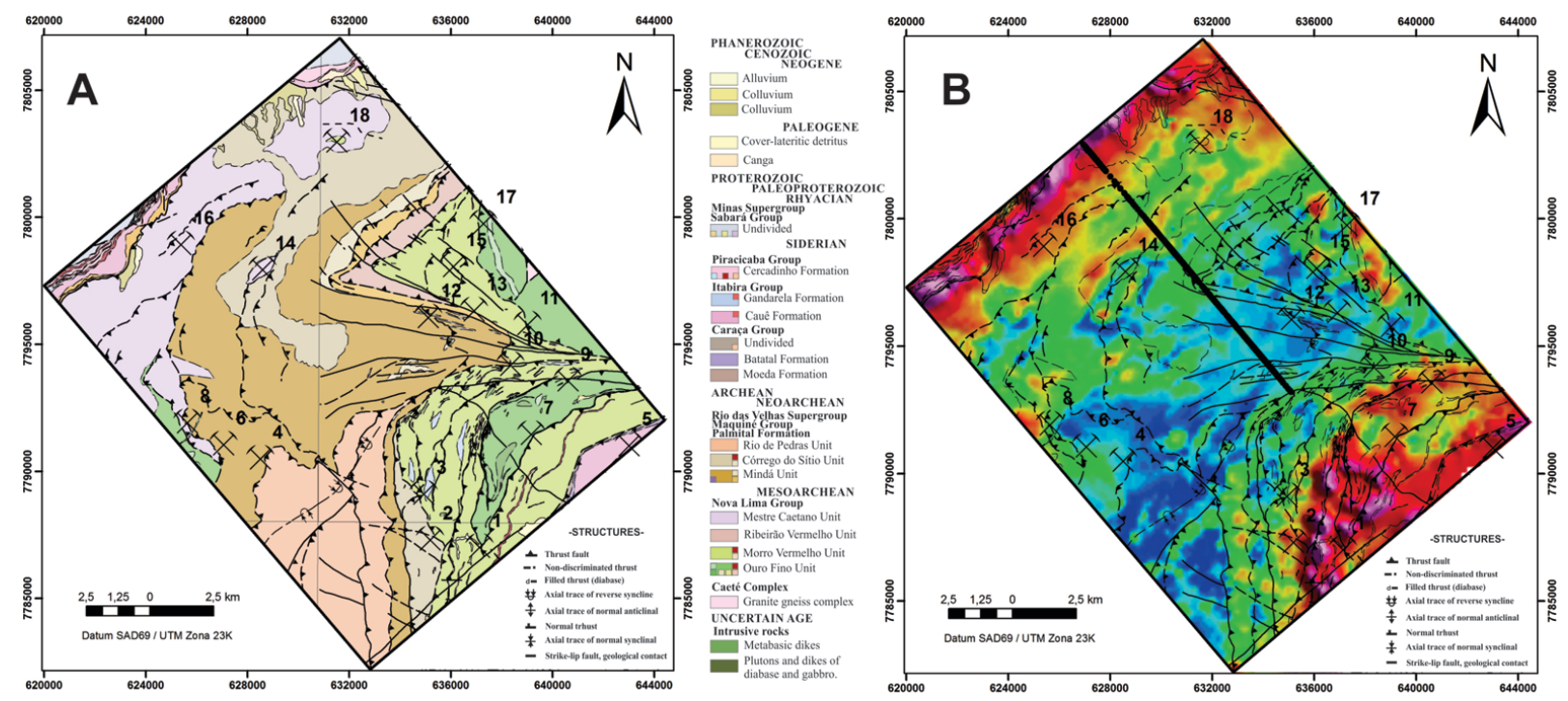

Figure 6 - (A) Geology map with the major structures in the area (Zucchetti \& Baltazar et al., 1998); (B) map of Analytic Signal showing defined contacts and major structures contacts and major structures (Zucchetti \& Baltazar, 1998).

ues increase of the magnetic anomaly, and consequently the reduction of Analytical Signal data values in the general direction of the dip (SE) of lithostratigraphic units of similar mineralogical composition. In Figure 6 such decrease in the data values of magnetic amplitude can be noticed from the rocks of the Mestre Caetano and Córrego do Sítio Units, in the northern area, to the contact with the Mindá Unit with Palmital Formation, in the southern area.

In addition to the magnetofacies observed and described, lineaments with structural trend NE-SW and NNE-SSW have been observed in the Analytical Signal map. The NE-SW lineaments located in the northern portion surrounds Lamego mine (Fig. 4, mine 14) and connect it to the Cuiabá mine (Fig. 4, mine 18). At the south of the area there is a NNE-SSW lineament associated with the contact of the quartzite from the Palmital Formation (Maquiné Group) with the Mindá Unit. Assessing the Analytical Signal map, in the Figure 4, the gold mines are located between low and high magnetic values and not over the high anomalies. According with Greg Hodges (Heffernan, 2013) a common complaint in gold exploration, as an example, is that the magnetic peaks do not correspond to the gold mineralization. But considering the process of alteration around a gold deposit and how that alteration would have reduced the magnetite in the host rock, it is clear that magnetic lows are more likely to indicate gold mineralization in most of the cases.

According to Baltazar et al. (1993), Endo (1997) and Araújo (2001), the São Vicente Shear Zone (SVSZ) presents sinistral directional kinematics, featuring a major crustal discontinuity and locus of significant gold mineralization. Madeira \& Barbosa (2012) present the electromagnetic map (HEM) of intermediate frequency $(4175 \mathrm{~Hz})$ with kilometrical sinistral kinematic structure in the surroundings of the SVSZ. In the apparent resistivity map (Fig. 7) such structure, with the sinistral rotational kinematics, is highlighted and the other structures with the same kinematics, but not that significant, can also be observed. In the same map (Fig. 7), the kilometrical linear structures to the north and to the east, which have low resistivity $(<3.710$ Ohm.m), and respectively featuring structural trend NE-SW and NNW-SSE, correspond to SVSZ by Zucchetti \& Baltazar (1998). These structures are represented in the inversion profile (Fig. 5), to the NW, presenting depths of up to $5000 \mathrm{~m}$.

In the Figures $6 \mathrm{~A}$ and 7 , the contact of Morro Vermelho Unit (a chemical-volcanosedimentary lithofacies composition, from the Mesoarchaean Age) and Moeda Formation (quartzite with intercalation of phyllite and conglomerate, from Paleoproterozoic Age) is clear. The first unit present low resistivity values and the second the highest resistivity values observed in the area. The Mindá Unit, composed by metapelites and metapsammites with preserved gradational stratification, presents low-intermediate resistivity evidencing gradational contact with the rocks from Rio de Pedras Unit, proximal metaturbidite with intermediate-high values of resistivity. In the contact of Morro Vermelho and Córrego do Sítio Units, in the southern portion, there is a linear structure trending NNE-SSW. Probably this structure has contributed 


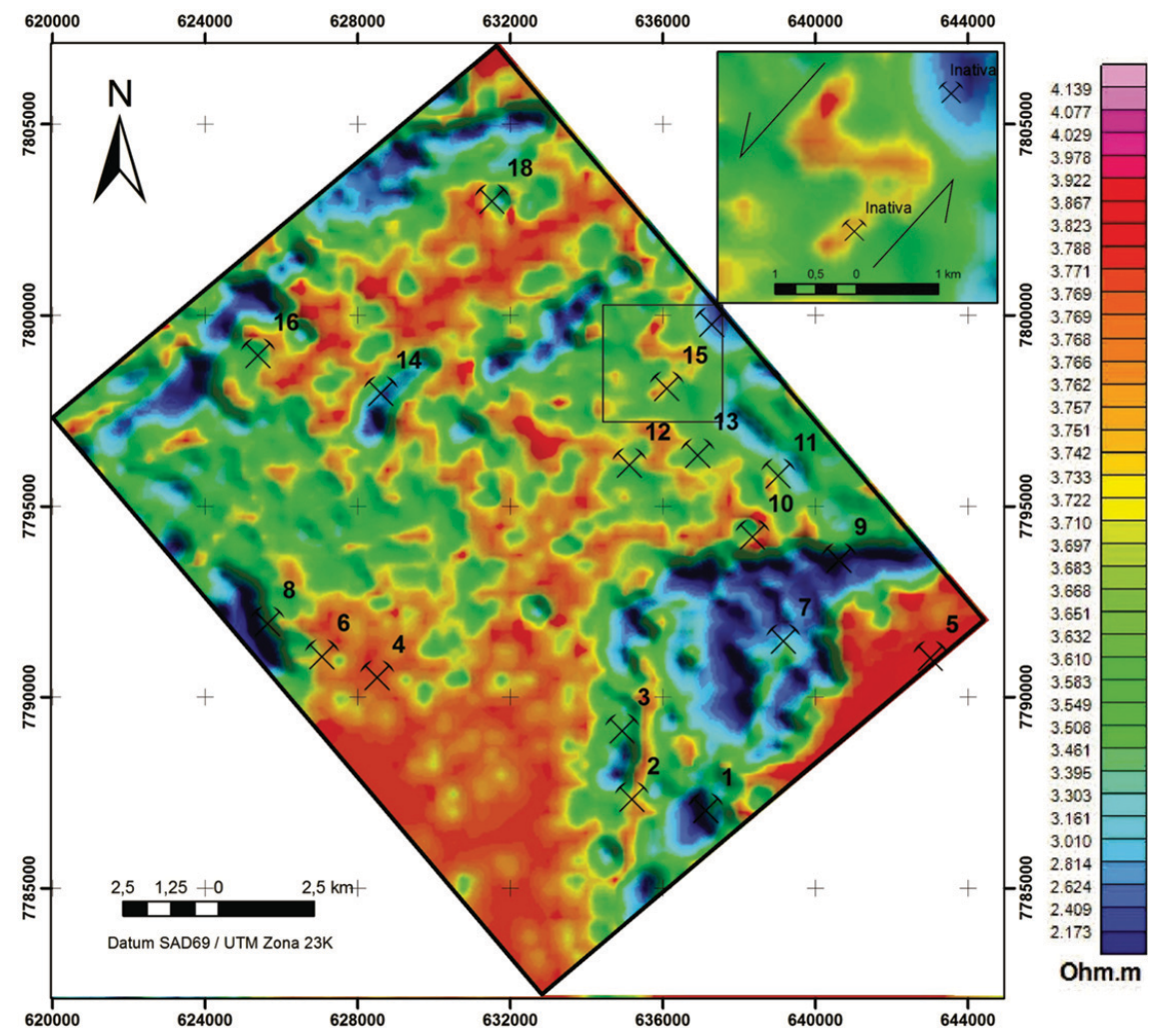

Figure 7 - In the mid-frequency electromagnetic map (Madeira \& Barbosa, 2012) it is possible to observe kilometric sinistral S structure.

to the mineralization of the two inactive mines (Fernandes and Cubatão) following this trend.

\section{Quantitative Analysis}

In the field, Madeira (2011) and Madeira \& Barbosa (2012) checked the accuracy of responses of the Euler deconvolution profiles, in the surface ground, and used the same methodology and systematics of the magnetic data applied to this work. Those authors verified that the responses of anomalies near to the surface are consistent with some structures shown by the Rio das Velhas Project maps (Zucchetti et al., 1996). These structures were found in the field in a radius smaller than $30 \mathrm{~m}$ than the place indicated by the inversions.

For the characterization of the structures related to the mechanisms and processes that rule the (re) mobilization and concentration of gold in the surroundings of the São Vicente Shear Zone, it was undertaken a deconvolution profile, for example, at the northern boundary of the area (Fig. 5). This profile shows the highest amplitude values of the magnetic data to the NW, with responses to the depth limit adopted for the study herein $-5000 \mathrm{~m}$. In the central part of the profile there are two structures with an average depth of $3500 \mathrm{~m}$ and a third one, fur- ther southeast, which also presents response at depth limit established of $5000 \mathrm{~m}$. It is noticed a horizontalization in the deeper structures of NW towards SE. The deconvolution responses from further southeast profile showed a mixture in parallel magnetic anomalies at the depth range of 750 to $1250 \mathrm{~m}$.

According to Araújo (2001), the ductile-brittle deformation and metamorphisms of the São Vicente Shear Zone, resulted in mineralization, where the fluids drained by pressure relief zones, causing the precipitation of sulfides and gold along the SVSZ. The structural evidences relates deformation to tectonic conveyance of rock units from the SE to the NW by thrust faults, directional and overlapping faults (Zucchetti \& Baltazar, 1998; Araújo, 2001). According to Fossen (2010), the faults and contractional shear zones represent a shortening of the crust or a layer of reference. When the surface of the crust is the reference, the contractional faults are exclusively reverse and thrust faults. The reverse faults dip angles are wider than the thrust faults and do not represent large magnitude of displacement as the thrust, featuring, however, a gradation between these two types of faults.

In the integrated geological/geophysical profile (Fig. 8), analyzing from the northwest towards the southeast, there is a gradation between verticalized fault, in the contact between Rio das 


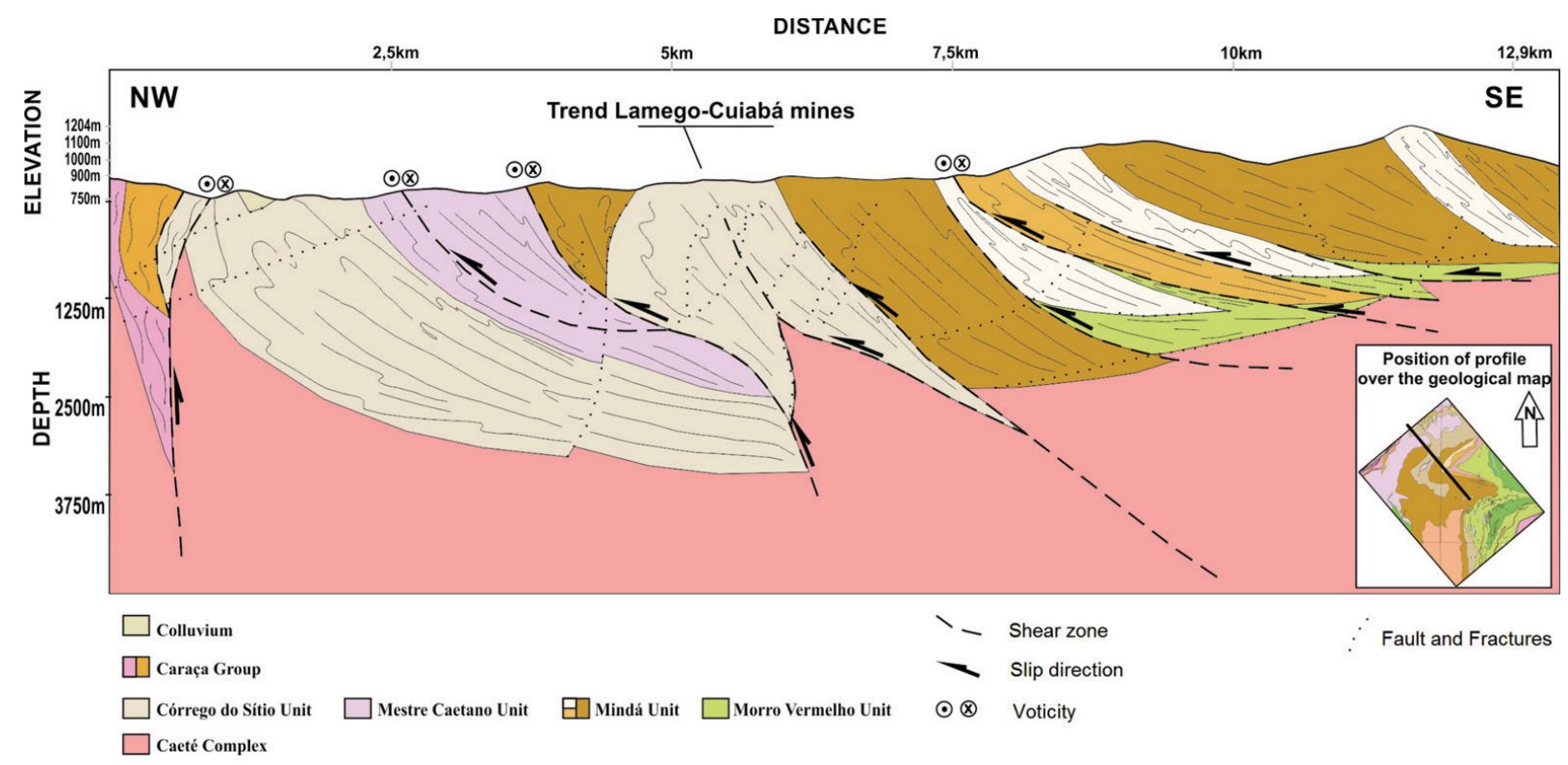

Figure 8 - Integration of geophysical and topographic profile with information of geology of the Rio das Velhas Project (Zucchetti et al., 1996).

Velhas and Minas Supergroup, and the horizontalized fault, in the contact of Mindá Unit with the Morro Vermelho Unit, featuring contractional faults resulting from the shortening of the crust. The geological/geophysical integration suggests deformation in the contractional regime (reverse and thrust faults) with convergence of tectonic conveyance to NW.

Araújo (2001) observing the SVSZ on its southern boundary, within the Mariana Municipality region, noticed that the structures have been developed within a range $3 \mathrm{~km}$ wide, involving psamopelitic units from the Nova Lima Group. Teixeira et al. (2006) estimated the depth of magnetic sources by means of Euler deconvolution, to support the understanding of the geometric behavior of São Vicente Shear Zone at depths, and showed that the fault dip is variable along its length. Teixeira et al. (2006) suggest that, generally, the fault attains shallow (200 to $400 \mathrm{~m}$ ) and some deep zones (400 to $800 \mathrm{~m}$ ).

Analyzing the Euler deconvolution profile (Fig. 5) and the integration of geological/geophysical profile (Fig. 8), undertaken in the northern boundery of the SVSZ, three main structures show depths of 3000-5000 m, covering a range $5 \mathrm{~km}$ wide at the ground surface. This last information can also be noticed in the mid-frequency electromagnetic map (Fig. 7), presenting lineaments of low resistivity and NE-SW structural trend, in the northern portion of the area, with variable width of $5-7 \mathrm{~km}$ between the faults.

The result of the interpolation of two-dimensional deconvolution profiles to generate a three-dimensional model is presented in the Figures 9, 10 and 11. The depths of the magnetic sources have been splitted into five intervals, 19.34-363.74 m, 363.75657.22 m, 657.23-1035.66 m, 1036.67-1581.13 m, 1581.14$3393.84 \mathrm{~m}$ respectively in the blue, green, yellow, red and magenta colours.

Baltazar et al. (1993), while describing the eastern boundary of the QFe, suggested that zones of high strain rate taken over by a complex of overlapping scales of tectonic thrust, including crystalline sheets, provided the migration and precipitation of auriferous hydrothermal solutions, during obvious epigenetic phenomena and strongly related to one or more Proterozoic crustal shortening events which have affected not only the supracrustal rocks, as well as the surrounding areas. In the Figure 9, the deep anomalies presented responses in a structural trend of NW-SE. In the eastern and western boundaries of the area (Fig. 9) this structural alignment is supported by the gold mines alignment, presenting strong relation of the NW-SE structures to the mineralization in the area. In the eastern portion of the map, it is still noticed the inflection from NW-SE to NESW of the related structures with the São Vicente Shear Zone of Zucchetti \& Baltazar (1998).

The magnetic anomalies, which depend on the shape, depth and orientation of the body, are generated by the magnetization contrast between the rocks. In the Analytical Signal map (Fig. 6B), the Mindá Unit is the one that presents the lowest values of magnetization. Analyzing the 3D model, statically represented in the Figure 10, this unit appears to be the one with the greatest 


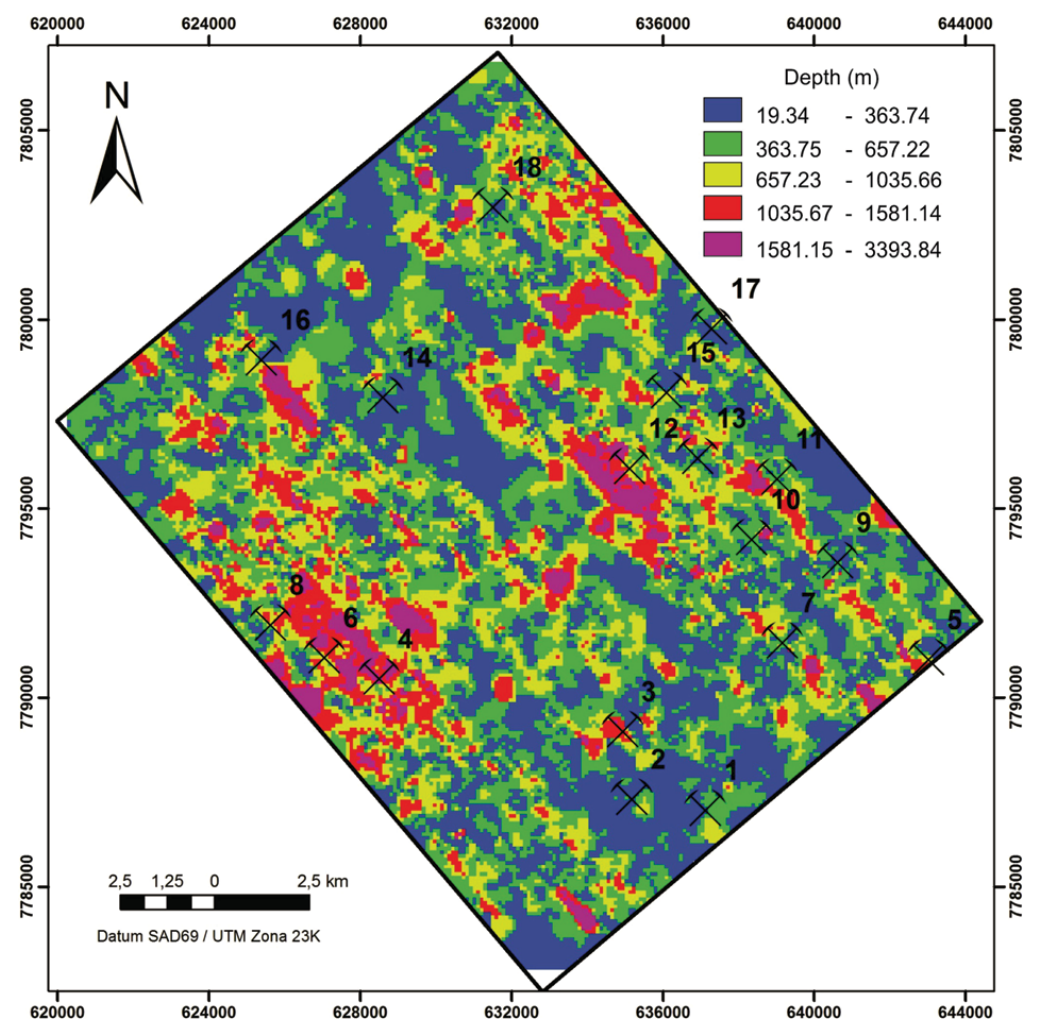

Figure $\mathbf{9}$ - Result of the interpolation of two-dimensional deconvolution profiles presenting the tectonic compartmentation of the area.

roof depth of the anomaly source. This fact is related to low magnetic susceptibility of sedimentary rock and depth to the basement top, it has magnetization data values greater than superimposed resedimentary unit. The regions with the lowest depth responses, or high magnetization, are related to the basal (ultra) basic metavolcanic rocks, Morro Vermelho and Ouro Fino Units, in addition to the Paleoproterozoic Age supracrustal rocks of the Minas Supergroup.

The Figure 11A presents the Lamego and Cuiabá Mines on one NE-SW lineament connecting the mines in depths exceeding $657 \mathrm{~m}$. The mines to the west of the area (Fig. 11B) are conditioned by two major deep structures, exceeding $1000 \mathrm{~m}$, featuring NW-SE structural trend. In the Figure 11C, the mines, located at the boundary of the Paciência Lineament (Scarpelli, 1991), are aligned according with the NW-SE direction (sub) parallel to the mixture of structural lineaments that, in this location, have depths exceeding $1500 \mathrm{~m}$.

\section{CONCLUSIONS}

The interpretation and qualitative analysis of the magnetic data, Analytical Signal map, was a significant contribution to determine structural lineaments and to split the magnetofacies for the lithos- tratigraphic units. Geometric parameters, such as the location of geological and structural limits, and depth of the bodies also provided excellent results with the Analytical Signal map. Electromagnetic data provided the identification of regions related to the gold bearing bodies and structures (rotational and lineaments) that contributed to the mineralization in the region. The magnetic inversion over the Analytical Signal map allowed to estimate the continuity at depth of structures and lithostratigraphic units, including the repetition of layers. The three-dimensional interpolation resulting in two-dimensional magnetic data inversion profiles allowed the tectonic partitioning of the lithostratigraphic and visualization of megastructures that have made this region the largest gold bearing host within the Quadrilátero Ferrífero.

The Structural Analysis represents simplified descriptions of the processes that form the structures. The deformation in some structures are too complex to be adjusted by means of a simple kinematic model (Groshong, 1999). The result of inversions and subsequent two-dimensional interpolation profiles generated well-defined structures for the depth of $5000 \mathrm{~m}$, but we shall carefully consider the simplification used in the models and use experimental and field data at the planning and assessment of the results. 


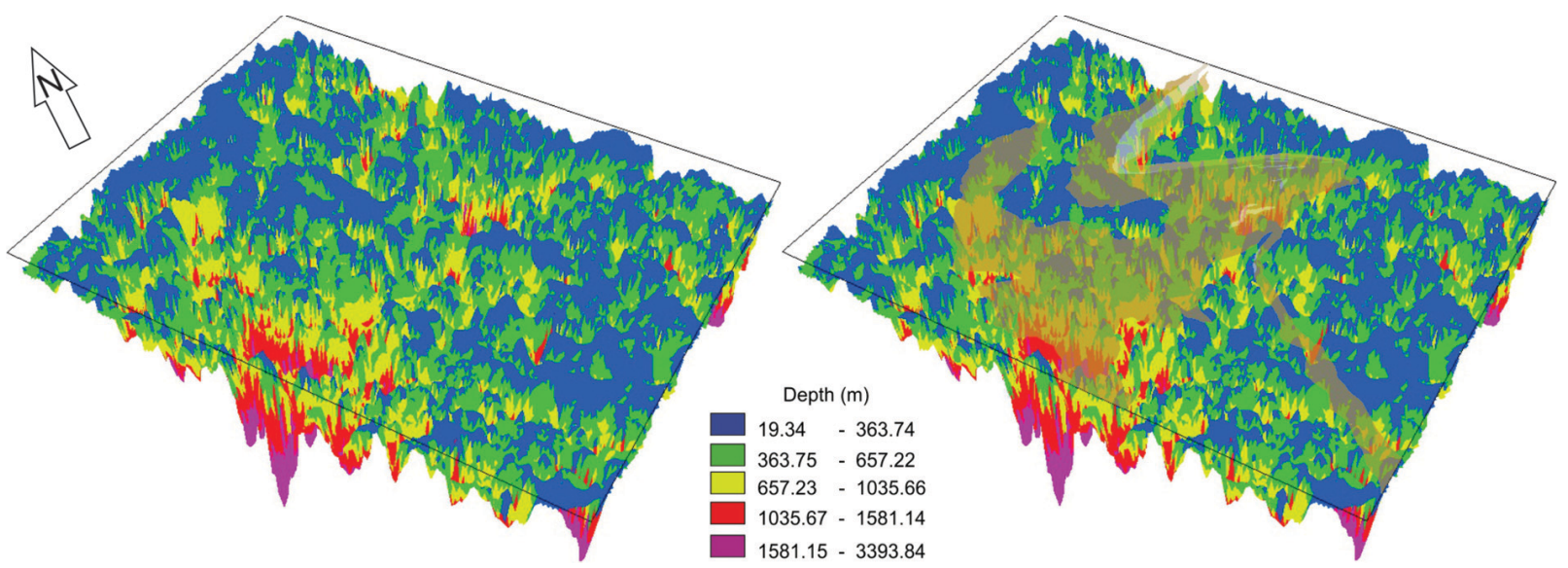

Figure 10 - Results in 3D interpolation, with vertical exaggeration of 2x, of 2D profiles is presented with Mindá Unit highlighted.
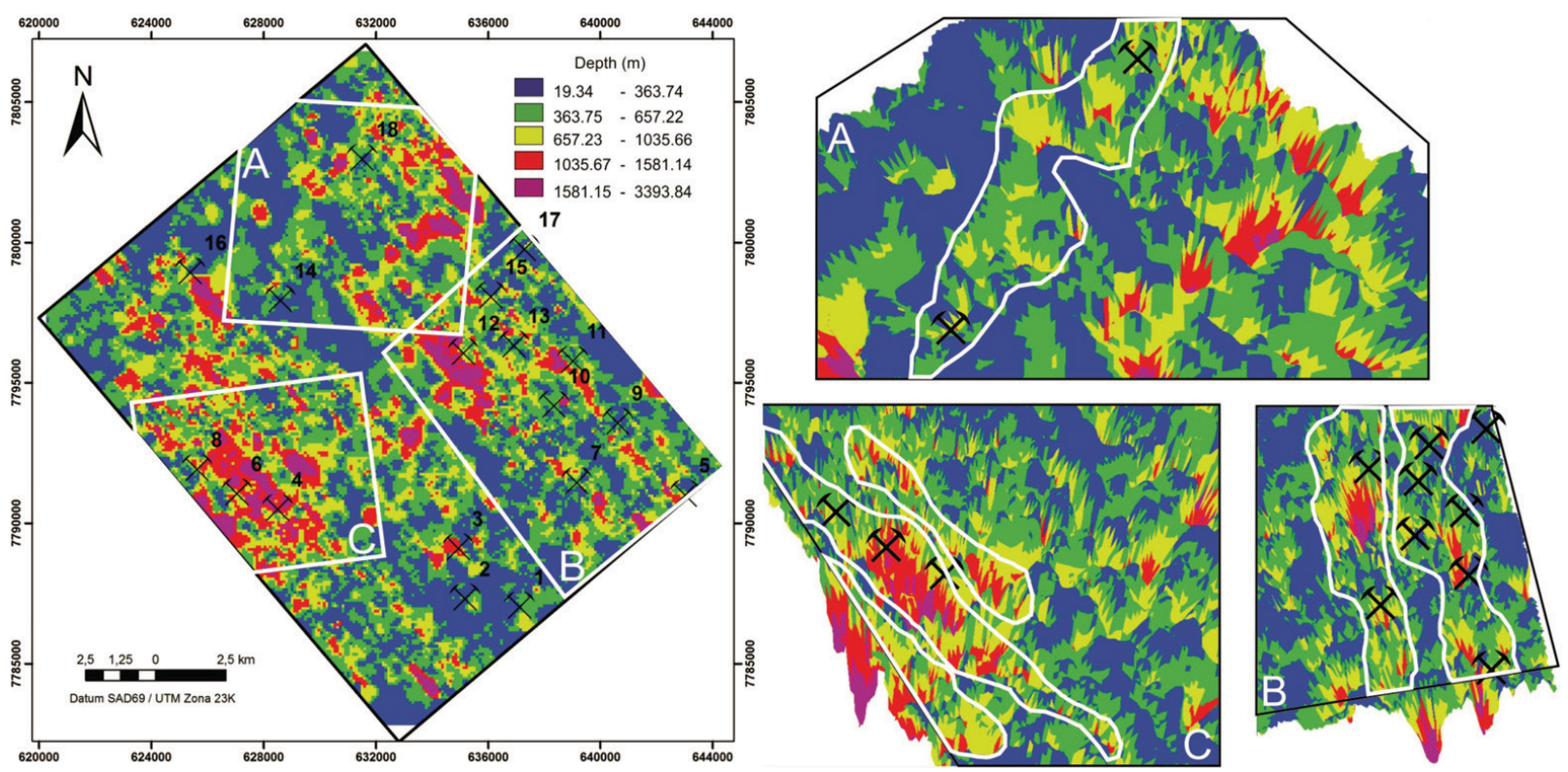

Figure 11 - The image shows the location of the mines, actives and inactives, and their relationship to major structures in depth. (A) 14 - Lamego and 18 - Cuiabá; (B) 5 - Congo Soco, 7 - 0jeriza, 9 - Soares, 10 - Carrapato/Caeté, 11 - Juca Vieira, 12 - Carrancas, 13 - Tinguá, 15 - Veremos, 17 - Adão; (C) 4 - Morcego, 6 - Morro das Bicas, 8 - Raposos.

Briefly, the study shows that the correct use of tools are significantly important and effective for geological structures recognition at depth and their relations, as well as for mineral exploration campaigns, improving programs by maximizing the rate of area coverage and minimization of required boreholes. This technique shows an economically and environmentally feasible and effective manner for the consolidation of the subsurface information. This systematics was proven in several areas (private data) with a higher degree of confidence than $90 \%$ in involved depth.

\section{ACKNOWLEDGEMENTS}

We would like to thank CPRM - Serviço Geológico do Brasil for the permission to use the geological and geophysical data for academical purposes.

\section{REFERENCES}

ALKMIM FF \& MARSHAK S. 1998. The Transamazonian orogeny in the Quadrilátero Ferrífero, Minas Gerais, Brazil: Paleoproterozoic collision and collapse in the Southern São Francisco Craton region. Precambrian Research, 90: 29-58. 
ALKMIM FF, MARSHAK S, EVANGELISTA HJ \& BRUECKNER H. 1994. Manifestações do evento transamazônico no Quadrilátero Ferrífero. In: Congresso Brasileiro de Geologia, 38., 1994, Camboriú. Proceedings... Camboriú, Brazil: SBG, 1994. 1: 75-76.

ALMEIDA FFM. 1977. O Cráton do São Francisco. Revista Brasileira de Geociências, 7(4): 349-364.

ALMEIDA LG. 2004. Estratigrafia e geologia estrutural da porção central do sinclinal Dom Bosco, Quadrilátero Ferrífero - Minas Gerais. Master Dissertation, Dept. of Geology, Universidade Federal de Ouro Preto, Minas Gerais, Brazil, 2004. 109 pp.

ARAÚJO JGM. 2001. Influência das zonas de cisalhamento de São Vicente e Tapera na mineralização aurífera do Quadrilátero Ferrífero, Minas Gerais. Master Dissertation, Inst. of Geoscience, Universidade de Brasília, Brasília, Brazil, 2001. 103 pp.

BALTAZAR OF \& ZUCCHETTI M. 1998. Rio das Velhas Project. Explicative Note of integrating geological map, 1:100.000 scale. DNPM/CPRM, Belo Horizonte, Brazil.

BALTAZAR OF, RAPOSO FO \& MATTOS GMM. 1993. Programa Levantamentos Geológicos Básicos do Brasil - PLGB - Folha Mariana SF.23X-B-I, 1:100.000 scale. DNPM/CPRM, Brasília, Brazil.

BALTAZAR OF, BAARS FJ, LOBATO LM, REIS LB, ACHTSCHIN AB, BERNI GV \& SILVEIRA VD. 2005. Mapas Geológicos do Quadrilátero Ferrífero na escala 1:50.000 com nota explicativa. In: LOBATO LM (Ed.). Projeto Geologia do Quadrilátero Ferrífero - integração e correção cartográfica em SIG com nota explicativa. CODEMIG. Belo Horizonte, Brazil.

BIZZI LA, SCHOBBENHAUS C \& VIDOTTI RM. 2003. Geologia, Tectônica e Recursos Minerais do Brasil: texto, mapas e SIG. Brasília, Brazil: CPRM, 2003. 674 pp.

CORREA NETO AV \& BALTAZAR OF. 1995. Compartimentação estrutural do Greenstone Belt Rio das Velhas no interior do Quadrilátero Ferrífero (MG). In: Simpósio Nacional de Estudos Tectônicos, 5., 1995, Gramado. Proceedings... Gramado, Brazil: SBG, 1995. p. 15-17.

CPRM - Serviço Geológico do Brasil. 2011. Projetos da Série 3000. Available on: <www.cprm.gov.br/aero/3000/aer03000.htm>. Access on: September 28, 2011.

DURRHEIM RJ \& COOPER GRJ. 1998. EULDEP: A program for the Euler deconvolution of magnetic and gravity data. Elsevier. Computers \& Geosciences, 24(6): 545-550.

ENDO I. 1997. Regimes tectônicos do arqueano e proterozóico no interior da placa Sanfranciscana: Quadrilátero Ferrífero e áreas adjacentes, Minas Gerais. PhD Thesis, Inst. of Geoscience, Universidade de São Paulo, São Paulo, Brazil, 1997. 243 pp.

ENDO I, OLIVEIRA AH, PERES GG, GUIMARÃES MLV, LAGOEIRO LE, MACHADO R, ZAVAGLIA G, ROSAS CF \& MELO RJ. 2005. Nappe Curral: Uma Megaestrutura Alóctone do Quadrilátero Ferrífero e Controle da mineralização. In: Simpósio Nacional de Estudos Tectônicos,
10., 2005, Curitiba. Proceedings... Curitiba, Brazil: SBG, 2005. p. 279281.

FOSSEN H. 2010. Structural Geology. Cambridge University Press. 4 ed., 1: 463 pp.

GROSHONG R. 1999. 3-D Structural Geology: A practical guide to surface and subsurface map interpretation. Berlin: Springer-Verlag. 2 ed., 1: $410 \mathrm{pp}$.

HEFFERNAN V. 2013. Airborne EM methods: be wary of relying on the tried and true. Available on: <http://www.earthexplorer.com/2013/Airborne_EM_methods_be_wary_of_relying_on_the_tried_and_true.asp $>$. Access on: March 15, 2013.

HILDENBRAND JD \& PEREZ DA GAMA MF. 1993. Levantamento aeromagnetométrico, gamaespectométrico e eletromagnético. Rio das Velhas Project. Final Report, V1, Technique Note, Prospec S/A, 47 pp.

KEATING P \& PILKINGTON M. 2004. Euler deconvolution of the analytic signal and its application to magnetic interpretation. Geophys. Prospect., 52: 165-182.

LADEIRA EA. 1991. Genesis of Gold in Quadrilátero Ferrífero: A remarkable case of permanency, recycling and inheritance - A tribute to Djalma Guimarães, Pierre Routhier and Hans Ramberg. In: LADEIRA EA (Ed.). Economics, Geology, Geochemistry and Genesis of Gold Deposits, p. 11-30, Proceeding, Rotterdam, A. Balkema.

MADEIRA TJA. 2011. Análise qualitativa e quantitativa geológica/geofísica para prospecção de ouro na porção nordeste do QFe. Monograph 12, Dept. of Geology, Universidade Federal de Ouro Preto, Minas Gerais, Brazil, 2011.74 pp.

MADEIRA TJA \& BARBOSA MSC. 2012. Inversão de dados magnetométricos aplicada a prospecção de ouro na porção nordeste do Quadrilátero Ferrífero. In: Simpósio Brasileiro de Geofísica, 5., 2012, Salvador. Proceedings... Salvador, Brazil: SBGf, 2012. CD-ROM.

REID AB, ALLSOP JM, GRANSER H, MILLETT AJ \& SOMERTON IW. 1990. Magnetic interpretation in three dimensions using Euler deconvolution. Geophysics, 55: 80-91.

ROLIM VK \& ALKMIM FF. 2004. Geometria 3D de falhas de empurrão e dobras associadas como expressões da morfologia do descolamento basal: resultados de uma simulação computacional. Revista Brasileira de Geociências, 34(3): 295-302.

SCARPELLI W. 1991. Aspects of gold mineralization in the Iron Quadrangle, Brazil. In: LADEIRAEA (Ed.). Economics, Geology, Geochemistry and Genesis of Gold Deposits, p. 1151-1157, Proceeding, Rotterdam, A. Balkema.

TEIXEIRA W, CARNEIRO MA, NOCE CM, MACHADO N, SATO K \& TAYLOR PN. 1996. Pb, $\mathrm{Sr}$, and $\mathrm{Nd}$ isotope constraints on the Archean evolution of gneissic-granitoid complexes in the southern São Francisco Craton, Brazil. Precambrian Research, 78: 151-164. 
TEIXEIRA AA, SILVA AM, PIRES ACB, MORAES RAV \& SOUZA FILHO CR. 2006. Integração e Análise de dados aerogeofísicos por meio da aplicação de técnicas de processamento digital de imagens e classificação não supervisionada: 0 exemplo do Greenstone Belt Rio das Velhas, Quadrilátero Ferrífero, MG. Brazilian Journal of Geophysics, 24(4): 559-572.

TELFORD WM, GELDART LP \& SHERIFFRE. 1990. Applied Geophysics. Cambridge University Press. 2 ed., 770 pp.
THOMPSONDT. 1982. EULDPH. A new technique for making computerassisted depth estimates from magnetic data. Geophysics, 47: 31-37.

ZUCCHETTI M, BALTAZAR OF \& RAPOSO F0. 1996. Estratigrafia. In: Companhia de Pesquisa de Recursos Minerais. Projeto Rio das VeIhas - Explicative Note of integrating geological map, 1:100.000 scale. DNPM - Departamento Nacional de Produção Mineral/CPRM - Serviço Geológico do Brasil. Belo Horizonte, Brazil, 13-42.

Recebido em 6 maio, 2014 / Aceito em 18 janeiro, 2016

Received on May 6, 2014 / Accepted on January 18, 2016

\section{NOTES ABOUT THE AUTHORS}

Thiago José Augusto Madeira. Graduated in Geological Engineer at School of Mine - Universidade Federal de Ouro Preto (2011). Throughout academic degree, performed as exploration geologist in IAMGOLD Corporation and KINROSS Gold Corporation. Additionally, worked as open pit mine geologist in Jaguar Mining (2011), and underground mine geologist AngloGold Ashanti (2012). Currently, master's degree student in Crustal Evolution and Natural Resources at Universidade Federal de Ouro Preto, with focus on Euler deconvolution over Potential Data and Structural Geology.

Maria Silvia Carvalho Barbosa. Graduated in Geological Engineer at School of Mine - Universidade Federal de Ouro Preto (1987). Master degree in Crustal Evolution and Natural Resources at Universidade Federal de Ouro Preto (1990). Ph.D. in Geophysics at Universidade de São Paulo. Currently, performing as a geophysicist in Gorceix Fundation and Associate Professor in Universidade Federal de Ouro Preto. Experience on Geoscience area with aim Mathematical Modeling. Performing in Geophysics, Geophysical Prospection, Potential methods and Applied Geophysics.

Antonino Juarez Borges. Graduated in Mining Engineer at School of Mine - Universidade Federal de Ouro Preto (1971), post graduated in Applied Geophysics at Universidade Federal da Bahia (1974), post graduated in Gemology at Universidade de São Paulo (1972), post graduated in Potential methods at CPRM (1988), post graduated in Electromagnetic methods at Brazilian Geophysical Society (1993), and post graduated in Airborne Geophysical Prospecting at ADIMB (1998). Currently, performing as a geophysicist in CPRM. 